\title{
Chk1 is an essential kinase that is regulated by Atr and required for the $G_{2} / M$ DNA damage checkpoint
}

\author{
Qinghua Liu, ${ }^{1-3}$ Saritha Guntuku, ${ }^{1,2}$ Xian-Shu Cui, ${ }^{4}$ Shuhei Matsuoka, ${ }^{1,2}$ David Cortez, ${ }^{1,2}$ \\ Katsuyuki Tamai, ${ }^{7}$ Guangbin Luo, ${ }^{1,5}$ Sandra Carattini-Rivera, ${ }^{1,5}$ Francisco DeMayo, ${ }^{6}$ \\ Allan Bradley, ${ }^{1,5}$ Larry A. Donehower, ${ }^{4,6}$ and Stephen J. Elledge, ${ }^{1,2,5,8}$

\begin{abstract}
${ }^{1}$ Howard Hughes Medical Institute, ${ }^{2}$ Verna and Marrs McLean Department of Biochemistry, ${ }^{3}$ Program in Cell and Molecular Biology, ${ }^{4}$ Department of Molecular Virology and Microbiology, ${ }^{5}$ Department of Molecular and Human Genetics, and ${ }^{6}$ Department of Molecular and Cellular Biology, Baylor College of Medicine, Houston, Texas 77030 USA; ${ }^{7}$ Medical and Biological Laboratories Co., Ltd., Ina, Nagano 396-0002, Japan
\end{abstract}

Chk1, an evolutionarily conserved protein kinase, has been implicated in cell cycle checkpoint control in lower eukaryotes. By gene disruption, we show that $C H K 1$ deficiency results in a severe proliferation defect and death in embryonic stem (ES) cells, and peri-implantation embryonic lethality in mice. Through analysis of a conditional $C H K 1$-deficient cell line, we demonstrate that ES cells lacking Chk1 have a defective $G_{2} / M$ DNA damage checkpoint in response to $\gamma$-irradiation (IR). CHK1 heterozygosity modestly enhances the tumorigenesis phenotype of WNT-1 transgenic mice. We show that in human cells, Chk1 is phosphorylated on serine 345 (S345) in response to UV, IR, and hydroxyurea (HU). Overexpression of wild-type Atr enhances, whereas overexpression of the kinase-defective mutant Atr inhibits S345 phosphorylation of Chk1 induced by UV treatment. Taken together, these data indicate that Chk1 plays an essential role in the mammalian DNA damage checkpoint, embryonic development, and tumor suppression, and that Atr regulates Chk1.

[Key Words: Atr; Atm; Chk1; embryonic lethality; DNA damage; checkpoint]

Received March 20, 2000; revised version accepted May 1, 2000.

The ability of organisms to sense and respond to DNA damage is critical for their long-term survival. Consequently, cells have evolved an elaborate DNA damage response pathway that senses aberrant DNA structures and transmits a damage signal to effectors that act to enhance survival of the organism (Elledge 1996). Activation of the DNA damage response pathway results in transcriptional induction of genes involved in DNA repair, activation of DNA repair pathways, and arrest of cell cycle progression. In metazoans, cells experiencing DNA damage may also undergo apoptotic cell death, thereby preventing these cells from possibly contributing to tumorigenesis or other diseases. Because many genes involved in the regulation of DNA damage responses were originally identified based on their ability to control cell cycle progression, the DNA damage response pathway is also often referred to as the DNA damage checkpoint pathway.

The mammalian DNA damage response pathway consists of several families of conserved protein kinases. Two members of the phosphoinositol kinase (PIK) family, Atm and Atr, are at the top of this signal transduction cascade. Although related, Atm and Atr form two

${ }^{8}$ Corresponding author.

E-MAIL selledge@bcm.tmc.edu; FAX (713) 798-8717. distinct subfamilies in evolution. Atm is more closely related to Tell in Saccharomyces cerevisiae and Schizosaccharomyces pombe, whereas Atr (Cimprich et al. 1996; Keegan et al. 1996) is more closely related to Mec1 in S. cerevisiae, Rad3 in S. pombe, and Mei-41 in Drosophila melanogaster (for review, see Elledge 1996). The ATM gene is mutated in the familial neural degeneration and cancer-predisposition syndrome ataxia telangiectasia (Savitsky et al. 1995). ATM deficient mice are viable, but show growth retardation, infertility, and cancer predisposition (Barlow et al. 1996; Xu et al. 1996). ATM mutant cells are defective for DNA damage checkpoints and are very sensitive to agents that cause doublestranded DNA breaks, such as $\gamma$-irradiation (IR). Like ATM mutant cells, yeast tel1 mutants have short telomeres, but they have intact cell cycle checkpoints and display only limited sensitivity to DNA-damaging agents. Less is known about Atr due to a lack of ATR mutant cells. However, overexpression of a kinase-defective Atr mutant abrogates cell cycle arrest after DNA damage, revealing a role in DNA damage checkpoints (Cliby et al. 1998; Wright et al. 1998). ATR disruption in mice results in peri-implantation embryonic lethality and fragmented chromosomes (Brown and Baltimore 2000). In D. melanogaster, mei-41 mutant embryos cannot properly lengthen the cell cycle at the midblastula 
transition and this leads to embryonic lethality (Sibon et al. 1999).

Downstream of Atm and Atr are two families of protein kinases, Chk1 and Chk2. The Chk2 family consists of Rad53 in $S$. cerevisiae and Cds1 in S. pombe (for review, see Elledge 1996), and Chk2/Cds1 in mouse and human (Matsuoka et al. 1998; Blasina et al. 1999; Brown et al. 1999; Chaturvedi et al. 1999). The Chk2 family kinases can be activated by DNA damage or replication blocks and this activation requires upstream PIK members in their respective species (Sanchez et al. 1996; Sun et al. 1996; Boddy et al. 1998; Lindsay et al. 1998). Chk2 is involved in DNA damage checkpoints because Chk2deficient embryonic stem (ES) cells fail to maintain $\mathrm{G}_{2}$ arrest after DNA damage (Hirao et al. 2000). $\mathrm{CHK}^{-/-}$ thymocytes are resistant to IR-induced apoptosis and fail to stabilize and activate p53 in response to IR /Chehab et al. 2000; Hirao et al. 2000).

The Chk1 kinase family consists of Chk1 in S. pombe (Walworth et al. 1993; Al-Kohairy et al. 1994), S. cerevisiae (Sanchez et al. 1999), and Xenopus laevis (Kumagai et al. 1998) and grapes in D. melanogaster (Fogarty et al. 1997; Sibon et al. 1997; Su et al. 1999). In S. cerevisiae, Chk1 controls the pre-anaphase arrest after DNA damage by preventing degradation of Pds1, an inhibitor of anaphase entry (Sanchez et al. 1999). In S. pombe and Xenopus, Chk1 is required for the $\mathrm{G}_{2}$ arrest induced by DNA damage, and in Xenopus for the prophase I arrest of oocytes (Nakajo et al. 1999). In S. pombe, Chk1 is phosphorylated in response to DNA damage in a Rad3-dependent manner and this is accompanied by an increase in 14-3-3 protein association (Walworth and Benards 1996; Chen et al. 1999). In D. melanogaster, grapes mutants display an embryonic lethal phenotype similar to that of mei-41 mutants. Although the phenotype of mei-41 and grapes mutants is complex, at least part of the defects is likely to be attributed to premature entry of mitosis.

Less is known about Chk1 function in mammals. In human cells, Chk1 is shown to be phosphorylated in response to IR and thus, is implicated in the DNA damage response pathway (Sanchez et al. 1997). Because yeast and human Chk1 can phosphorylate Cdc25C in vitro on the inhibitory phosphorylation site S216, Chk1 may function as an effector of the DNA damage checkpoint that activate $\mathrm{G}_{2}$ arrest by inhibiting Cdc2 kinase activities through Cdc25C. It is currently unclear, however, which PIK members are the regulators of Chk1 in mammalian cells. Thus, we generated a CHK1 knockout mouse and subsequently, a conditional CHK1-deficient ES cell line. Our results indicate that Chk1 is regulated by Atr and plays a crucial role in the $\mathrm{G}_{2} / \mathrm{M}$ DNA damage checkpoints, embryonic development, and tumor suppression. A model concerning the mammalian DNA damage response pathway will also be discussed.

\section{Results}

\section{Generation of a Chk1 knockout mouse}

We disrupted the CHK1 gene in murine ES cells by gene targeting. The targeting vector consists of a neo marker for positive selection flanked by $1.9 \mathrm{~kb}$ and $4.5 \mathrm{~kb}$ of CHK1 homologous sequences, and a TK marker for negative selection (Fig. 1A). Homologous recombination with this targeting vector removes $3 \mathrm{~kb}$ of CHK1 genomic sequence, including exons $2-5$ that encode the putative first methionine, the "G $\times \mathrm{G} \times \times \mathrm{G}$ " ATP-binding motif and half of the kinase domain. Thus, it is likely to generate a null allele. Eight Chk1 heterozygous ES clones were obtained from screening 192 G418- and FIAU-resistant colonies (Fig. 1B). Four independent cell lines were injected to generate chimeras, of which three produced germ-line transmission. The phenotype, as described below, was consistent among all different lines.

\section{Chk1 deficiency results in peri-implantation lethality}

CHK1 heterozygous mice are healthy, fertile, and tumorfree up to 1.5 years of age. However, when the heterozygous mice were intercrossed, no CHK1 homozygous mice were detected among 139 offspring, indicating that Chk1 deficiency results in embryonic lethality. Systematic analysis of embryonic day 6.5 (E6.5)-E15.5 embryos generated from heterozygotes matings failed to detect CHK1 null embryos at any stage examined (data not shown). Empty decidua and remains of resorbed embryos were often observed at E6.5 or E7.5 in heterozygotes intercross, but were rarely seen in backcross between heterozygous and wild-type mice (Fig. 1C; data not shown). These results suggest that the lethality of CHK1 null embryos may occur before E6.5.

Therefore, we isolated and cultured blastocysts from intercrossed CHK1 heterozygous females at E3.5. PCR genotyping of newly isolated blastocysts revealed that the fraction of CHK1 null embryos was always between one-seventh and one-sixth, well below the predicted onequarter Mendelian ratio. And these null embryos often displayed abnormal morphology distinctive from their wild-type or heterozygous littermates (data not shown). When these blastocysts were cultured in vitro up to 7 days, the majority would continue to proliferate, hatch from the zona pellucida on the first or second day in culture, and immediately attach or "implant" to the Petri dish surface (Fig. 2A). The trophoectoderm of blastocysts spread into a single cell layer and divided a few times before terminally differentiating into giant trophoblast cells. Above the trophoblast cells lay the inner cell mass (ICM), which continued to proliferate to generate a large cell mass. These proliferating blastocysts, by genotyping, consisted of only wild type and heterozygotes with a 1:2 ratio. In contrast, a small group of blastocysts would stop proliferation, fail to hatch, and degenerate inside the zona pellucida (Fig. 2A). These nonproliferative blastocysts were presumably the missing homozygous mutant embryos, however, their genotype could not be confirmed by PCR due to massive DNA fragmentation during embryo degeneration. Three mutant blastocysts hatched on the third or fourth day in culture, laying down a few trophoblast cells but no ICM. We obtained the genotype of two of these embryos and both were $\mathrm{CHK}^{-/-}$. These results suggested that $\mathrm{CHK}^{-/-}$ 
Figure 1. CHK1 disruption results in early embryonic lethality. (A) Disruption of the CHK1 gene in ES cells. (a) Chk1 protein structure. Located at the amino terminus are the " $\mathrm{G} \times \mathrm{G} \times \times \mathrm{G}$ " ATP-binding motif and kinase domain. (b) Restriction map of the wild-type CHK1 locus including exons 2-7 and location of the $3^{\prime}$ external and $5^{\prime}$ internal probes used for Southern blots shown below. (c) Restriction map of the neo targeting vector. The direction of transcription is shown by arrows beneath the neo and TK markers. (pBS) pBluescript plasmid. (d) Predicted restriction map of the targeted CHK1 allele. Only relevant restriction sites are shown. $(N c)$ NcoI; $(N d)$ NdeI; $(R v)$ EcoRV. $(B)$ Identification of $\mathrm{CHK}^{+/-}$ES clones by Southern blot analysis. (a) Genomic DNA was digested with NcoI and EcoRV and probed with the 3' external probe. Genotypes are shown above each lane. $\mathrm{CHK1}^{+/-}$ES clones showed a 10.5-kb wild-type and a $6.5-\mathrm{kb}$ mutant band as predicted. (b) Genomic DNA was digested with $\mathrm{NdeI}$ and probed with the $5^{\prime}$ internal probe. $\mathrm{CHK1}^{+/-}$ES clones displayed a 9.5-kb wild-type and a $7.0-\mathrm{kb}$ mutant band. (c) CHK1 genotyping by PCR. The wild-type and mutant CHK1 alleles generate a 282-bp and a 572-bp band, respectively. $(C)$ Morphological and histological analysis of E7.5 embryos isolated from $\mathrm{CHK}^{+/-}$intercrosses. A typical photograph is shown for normal $(a, c)$ and mutant $(b, d)$ E7.5 embryos freshly dissected from decidua $(a, b)$ or hematoxylin and eosin-stained sections of E7.5 decidua $(c, d)$.

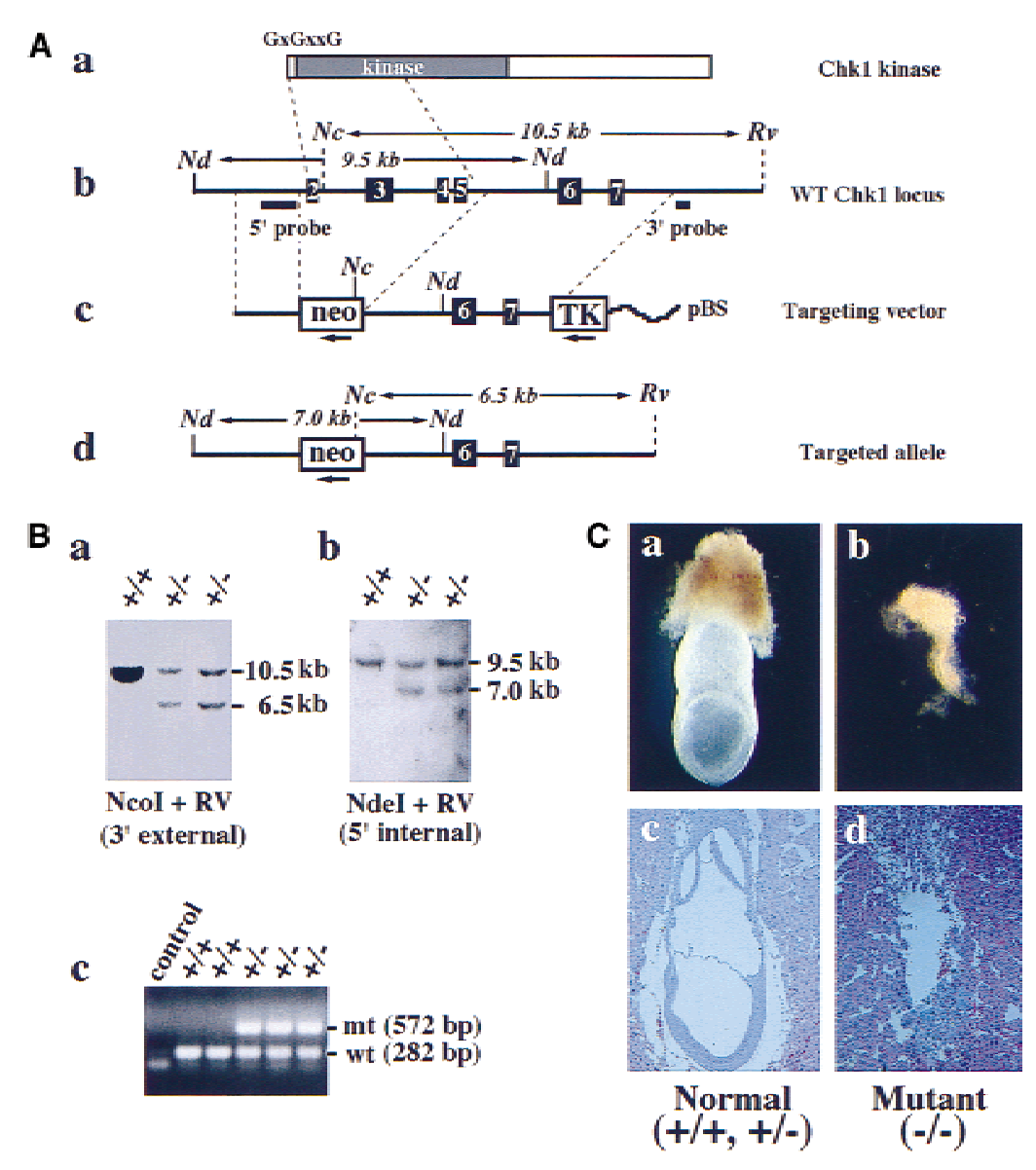

hallmark of apoptotic cells. Although wild-type and heterozygous littermates normally showed two to four fluorescent dots, CHK1 homozygous blastocysts displayed many fluorescent dots, indicative of massive apoptosis (Fig. 2D). To further confirm the TUNEL results, we stained these embryos with 4,6-diamidino-2-phenylindole (DAPI) and observed them under the confocal microscope. Indeed, many cells in $C H K 1^{-/-}$embryos had condensed and fragmented nuclei that is characteristic of apoptosis (Fig. 2E). These results suggest that CHK1-deficient embryos die of apoptosis at the blastocyst stage.

To determine whether p53 is responsible for the apoptosis observed in blastocysts, we mated $\mathrm{p} 53^{-/-} \mathrm{CHK} 1^{+/-}$ male and female mice, which is expected to generate p53 $3^{-/-}$mice with $\mathrm{CHK}_{1}^{+/+}, \mathrm{CHK1}^{+/-}$, and $\mathrm{CHK1}^{-/-}$genotype with a 1:2:1 ratio. Eight-cell morula were isolated from these intercrosses at E2.5, cultured for 2 days and picked for the TUNEL assay. The p53 null mutations could neither rescue nor delay the early lethality of $\mathrm{CHK1}^{-1-}$ embryos (data not shown). Furthermore,

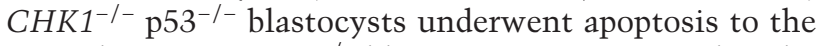
same degree as $\mathrm{CHK1}^{-/-}$blastocysts, suggesting that the apoptosis is independent of $\mathrm{p} 53$.

\section{Chk1 is essential for ES cell viability}

To investigate the function of Chk1 at the cellular level, we attempted to generate $\mathrm{CHK1}^{-/-}$ES cells by sequential 
A

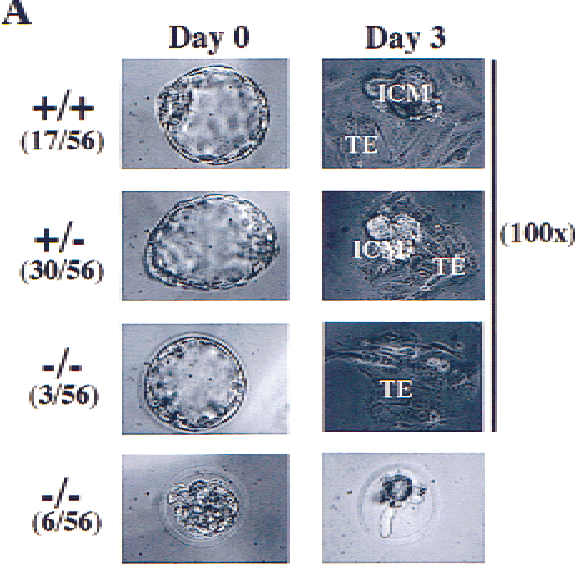

D

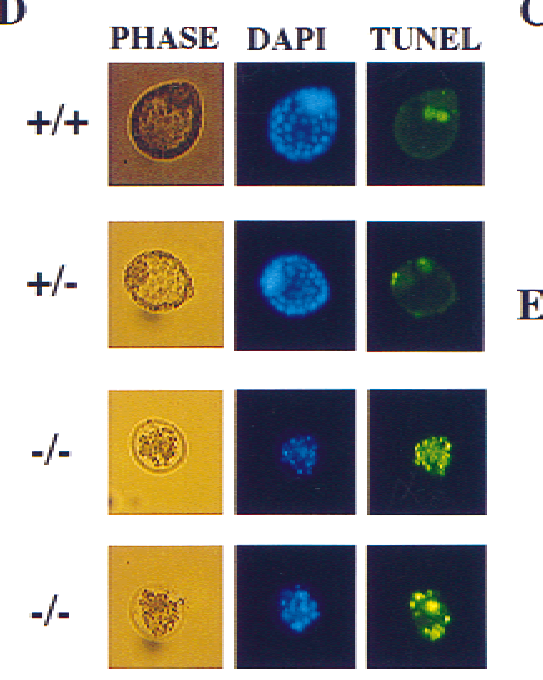

B
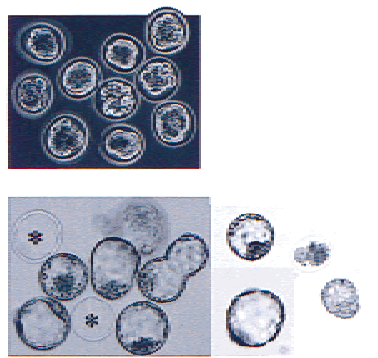

30h

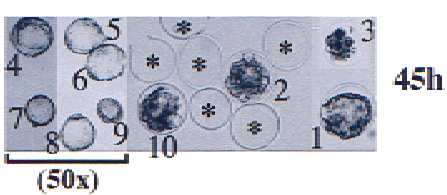

C

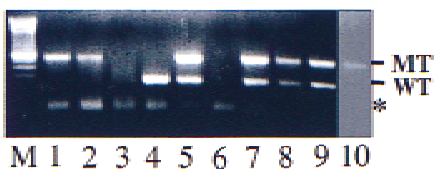

E

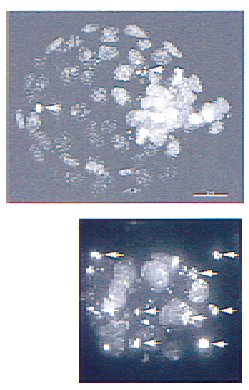

Normal

$(+/+,+/-)$

Mutant

$(-/-)$
Figure 2. In vitro culture of preimplantation embryos. $(A)$ In vitro culture of blastocysts isolated from $\mathrm{CHK}^{+/-}$intercrosses. A typical image at day 0 and day 3 are shown along with the percentage of each category. (TE) Trophoectoderm; (ICM) inner cell mass. All images are 320x except when otherwise indicated. $(B)$ In vitro culture of eight-cell morula. Shown here are a litter of 10 embryos isolated from a $\mathrm{CHK}^{+/-}$ intercross. The images were captured at 6, 30, and $45 \mathrm{hr}$ in culture $(100 \times$ except when otherwise indicated). The asterisks indicate the empty zona pellucida after the embryos have hatched. The embryos were individually picked and labeled 1-10. Embryos 1, 2, 3, and 10 failed to hatch. (C) PCR genotyping of embryos from $B$. The lane numbers correspond to that of the embryos. Embryo 6 was lost during transfer and embryo 3 was too degenerate to give any products. (WT) Wild type; (MT) mutant. The asterisk indicates a nonspecific band generated by primers alone. $(D)$ TUNEL analysis of blastocysts derived as described in $B(100 \times)$. (E) Confocal images (DAPI, 1000×) of blastocysts analyzed in $D$. The arrows indicate condensed and fragmented nuclei. gene targeting. A second targeting vector containing the hprt marker was constructed and used to transfect $\mathrm{CHK}^{+/-}$ES cells, in which one CHK1 allele was disrupted previously by neo. When selected for both markers, no targeting event could be obtained from 384 G418/ HAT/FIAU-resistant colonies. When selected only for hprt, 18 targeted clones were obtained after screening 351 HAT/FIAU-resistant colonies and in all cases the hprt construct had replaced the neo-disrupted mutant allele instead of the wild-type gene (data not shown). These results suggest that Chk1 is probably essential for proliferation or survival of ES cells.

Therefore, we constructed conditional CHK1-deficient ES cells by flanking the second exon of one CHK1 allele with $\operatorname{lox}_{P}$ sites and disrupting the other by gene targeting (Fig. 3A,B). This lox-flanked (flox) CHK1 allele can be converted into a null allele after excision of exon 2 by Cre-lox site-specific recombination because it contains the translational initiation sequence and encodes the ATP-binding site for the kinase. When three independent $C H K 1^{\text {flox/- }}$ cell lines were transfected transiently with a $C M V$ :Cre plasmid, no excised clones were detected by Southern blot analysis among total of $~ 400$ ES colonies (data not shown). However, when a control
CHK1 $1^{\text {flox/+ }}$ cell line was transfected with $C M V: C r e, 28 \%$ (25 of 88 ) of the colonies underwent $100 \%$ excision, whereas an additional $10 \%$ (9 of 88) underwent partial or postmitotic excision, generating chimeric colonies (data not shown). These results confirm our prediction that excision of exon 2 from the CHK1 gene generates a null allele, and are consistent with the previous finding that Chk1 plays an essential role in ES cells. Furthermore, the lack of chimeric excised colonies for Cre-transfected $C H K 1^{\text {flox/- }}$ cells suggests that the defects associated with $\mathrm{CHK}^{-/-}$cells are cell-autonomous and cannot be rescued by mixing with wild-type cells.

The absence of $\mathrm{CHK}^{-/-}$colonies could theoretically be explained by an inability of the $C H K 1^{\text {flox/- }}$ cells to excise or by cell death after the excision. To distinguish these two possibilities, we transfected both $C H K 1^{\text {flox/+ }}$ and $C H K 1^{\text {flox/- }}$ ES cells with a $P G K$ :Cre plasmid by electroporation and harvested cells after 24, 48, 72, and $96 \mathrm{hr}$. Southern blot analysis revealed that $C H K 1^{\text {flox } /-}$ cells underwent excision as efficiently as $\mathrm{CHK}^{\text {flox/+ }}$ cells (Fig. $3 \mathrm{C}$, cf. lanes 2,3 with lanes 6,7$)$. The excised and nonexcised cells were represented by the $7.5-\mathrm{kb}$ and $5.1-\mathrm{kb}$ band, respectively. Judging by their relative intensities, we estimated that $\sim 60 \%-70 \%$ of cells underwent flox 
Liu et al.

Figure 3. Construction and analysis of a conditional CHK1-deficient ES cell line. (A) Restriction maps of targeting vectors and targeted alleles. (a) hprt targeted allele; (b) hprt targeting vector; $(c)$ wild-type CHK1 locus; (d) flox targeting vector; $(e)$ flox ${ }^{\text {neo }}$-targeted allele; $(f)$ flox allele generated after neo excision; $(g)$ flox $\Delta$ allele generated after excision of exon 2 . Only relevant restriction sites are shown. $(N c)$ NcoI; (Nd) NdeI; $(R V)$ EcoRV. (B) A schematic representation of the construction of conditional CHK1-deficient ES cells. In brief, a CHK1 flox ${ }^{\text {neo }} /+$ cell line was first obtained using the flox-targeting vector followed by the Cre-loxP-mediated neo excision to create CHK1 $1^{\text {flox } /+}$ cells. The remaining wild-type gene was then disrupted in the $C H K 1^{\text {flox/+ }}$ cells by the hprt targeting vector to generate CHK1 $1^{\text {flox/- }}$ cells. Finally, CHK1 $1^{\text {flox/- }}$ cells were conditionally converted into $\mathrm{CHK}^{-/-}$cells by excision of exon 2 by transient transfection of PGK:Cre. (C) A Southern blot showing excision of the flox allele in $C H K 1^{\text {flox } /+}$ and CHK1 $1^{\text {flox/- }}$ cells. Both are sister cell lines obtained from the same screen for generating CHK1 $1^{\text {flox } /-}$ cells. The asterisk refers to a band produced by random integration of the hprt construct in the $C H K 1^{\text {flox/+ }}$ cells. Genomic DNA was prepared from untransfected (lanes $1,6)$ or Cre-transfected cells (lanes 2-5 and $7-10)$ collected at 24, 48, 72, and $96 \mathrm{hr}$ after electroporation, digested with NdeI and EcoRV and probed with the $5^{\prime}$ internal probe. $\Delta$ refers to the excised flox allele. The faint wild-type band present in lanes 2-4 was contributed by the feeder cells. $(D)$ Comparison of Cre-transfected $C H K 1^{\text {flox/+ }}$ and $C H K 1^{\text {flox/- }}$ cells by FACS (DNA content) analysis. Cells were harvested at 24,48 , and $72 \mathrm{hr}$ after electroporation and stained with propidium iodide (PI). The arrow indicates cells with less than $2 \mathrm{~N}$ DNA content that were present in the 72 -hr flox/sample.

A
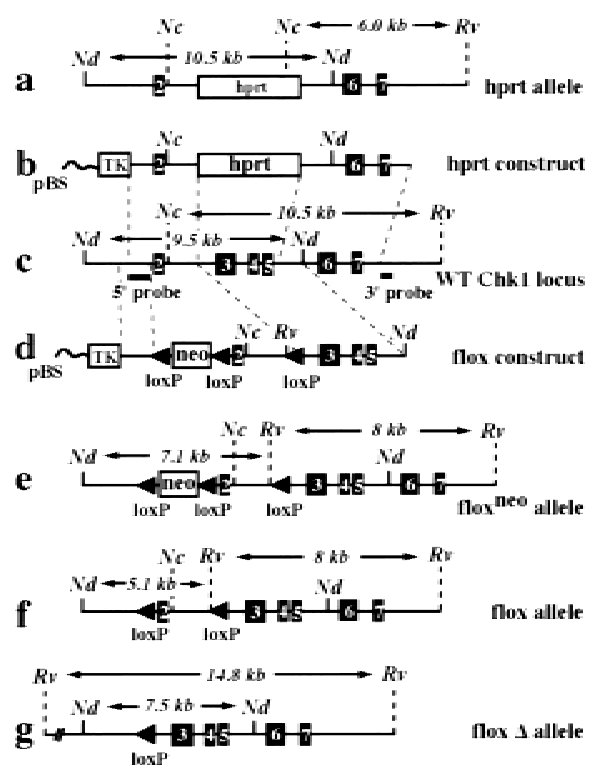

C

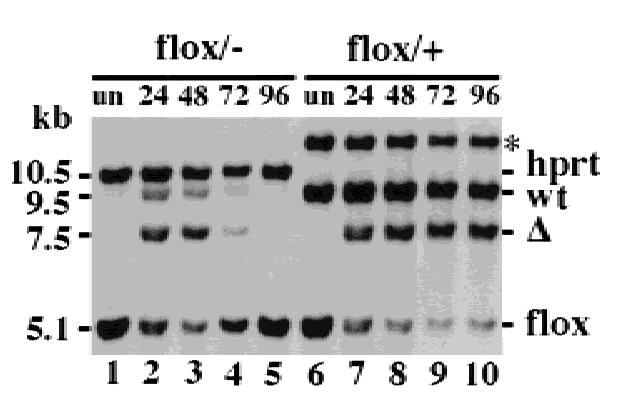

B

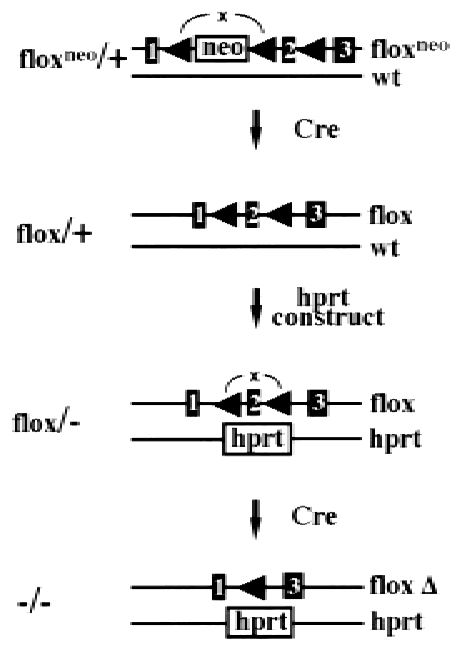

D

$24 \mathrm{~h}$

flox/- flox/+

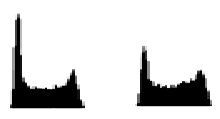

$48 \mathrm{~h}$

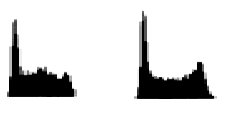

$72 h+\left.\left.\right|_{2 n 4 n}\right|_{2 n 4 n}$ excision in both cell lines by $48 \mathrm{hr}$ after Cre transfection (Fig. 3C, lanes 3,8). However, although the excised flox/+ cells divided as fast as the nonexcised cells, the excised flox/- cells disappeared from the culture between 72 and $96 \mathrm{hr}$ (Fig. 3C, cf. lanes 4,5 and lanes 9,10). Analysis of DNA content by FACS revealed a significant sub- $G_{1}$ population, which is characteristic of apoptotic cells, in the Cre-transfected $C H K 1^{\text {flox/- }}$ cells at $72 \mathrm{hr}$ after transfection (Fig. 3D). These results indicate that $\mathrm{CHK}^{-/-}$ cells have a severe proliferation defect accompanied by apoptotic death.

\section{$\mathrm{CHK}^{-/-}$cells are defective for the $G_{2} / M$ DNA damage checkpoint}

IR induces a predominant $G_{2}$ arrest in mouse ES cells (Aladjem et al. 1998; Hirao et al. 2000). To determine whether Chk1 is required for this $\mathrm{G}_{2}$ arrest, we subjected $\mathrm{CHK}^{\text {flox/- }}$ ES cells to $10 \mathrm{~Gy}$ of IR at $24 \mathrm{hr}$ after trans- fection with a PGK:Cre or a CMV:GFP plasmid. Twelve hours after irradiation, $\sim 70 \%-80 \%$ of all cell types arrested at $\mathrm{G}_{2}$ with a $4 \mathrm{~N}$ DNA content, as measured by FACS analysis (Fig. 4A). However, at later time points the $\mathrm{G}_{2}$-arrested population of $C H K 1^{\text {flox/- }}$ cells declined, whereas the $G_{1}-S$ population increased to $43.7 \%$ (18 hr) and $53.9 \%(24 \mathrm{hr})$, as more cells were converted to CHK1 ${ }^{-1-}$ cells (Fig. 4A). In contrast, all the control cells remained predominantly arrested at $\mathrm{G}_{2}$. These results suggest that $\mathrm{CHK}^{-/-}$cells may lack a functional $\mathrm{G}_{2} / \mathrm{M}$ DNA damage checkpoint.

To determine whether $\mathrm{CHK}^{-/-}$cells enter mitosis in the presence of DNA damage, we took advantage of the fact that mouse ES cells have a functional spindle checkpoint (Hirao et al. 2000). Cells were irradiated as described above and immediately placed in media containing nocodazole that will disrupt spindles and trigger a mitotic arrest. Twelve hours after IR and nocodazole treatment, $90 \%$ of all cell types arrested with a 4N DNA 
A

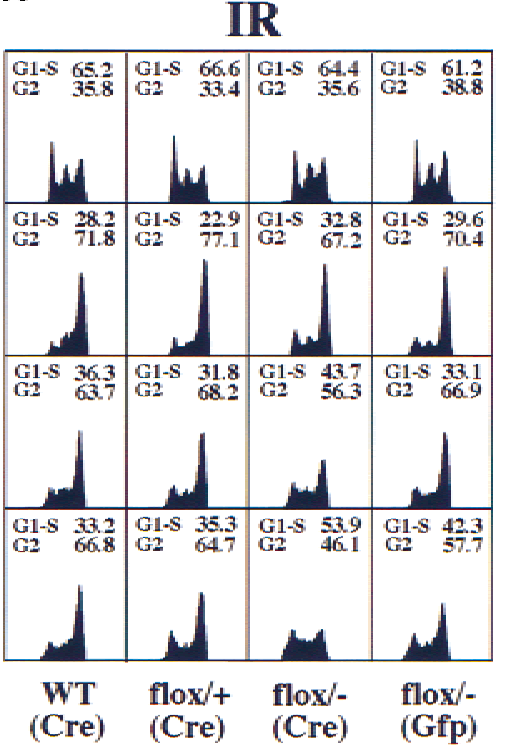

C
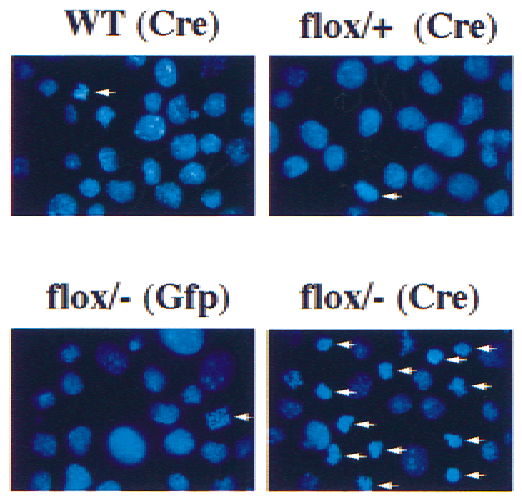

IR + Nocodazole
B
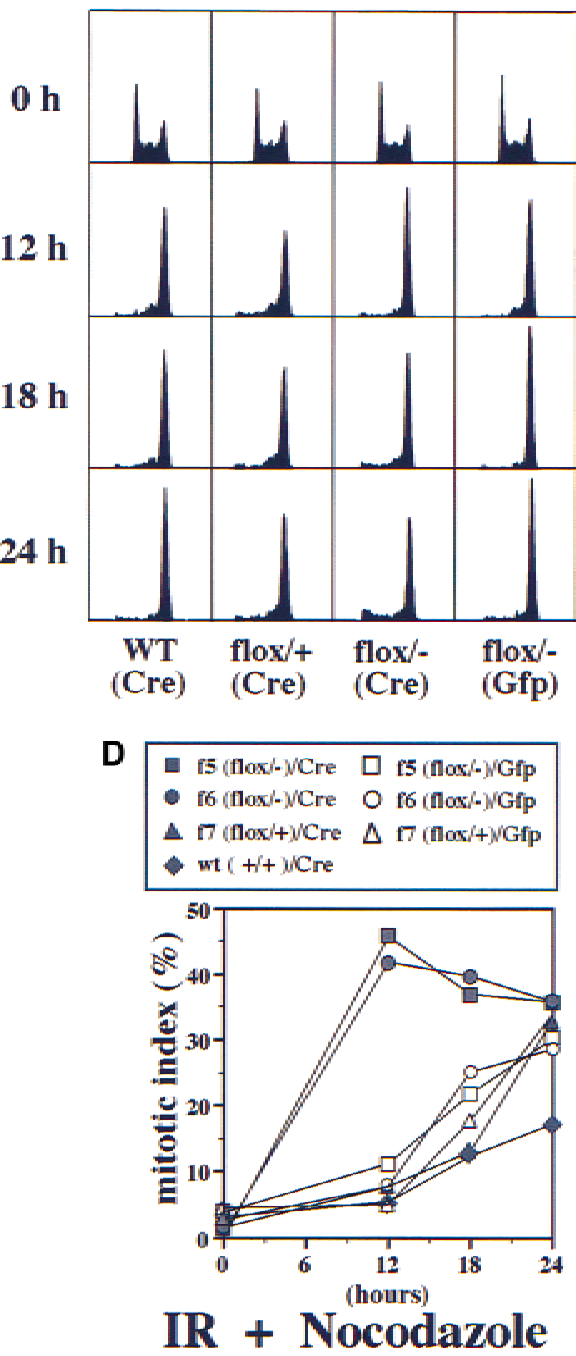

Figure 4. $\mathrm{CHK}^{-/-}$cells are defective for the $\mathrm{G}_{2} / \mathrm{M}$ DNA damage checkpoint. $(A)$ FACS (DNA content) analysis of irradiated GFP- or Cre-transfected $\mathrm{CHK1}^{+/+}, \mathrm{CHK}^{\text {flox/+ }}$ and $C H K 1^{\text {flox/- }}$ cells. Twenty-four hours after transfection, cells were subjected to 10 Gy IR, harvested at $0,12,18$, and $24 \mathrm{hr}$ and stained with PI. The percentage of $\mathrm{G}_{1}-\mathrm{S}$ and $\mathrm{G}_{2}$ population (mitotic cells are included in the $\mathrm{G}_{2}$ counts but are generally a small proportion) is shown above each FACS sample. (B) FACS (DNA content) analysis of IR and nocodazole-treated cells. Cells of the indicated genotypes were transfected and irradiated as in $A$ and incubated in nocodazole 10.2 $\mu \mathrm{g} / \mathrm{ml}$ ) containing media $30 \mathrm{~min}$ after irradiation. $(C)$ Images $(1000 \times)$ of the DAPIstained 12-hr samples in B. Arrows indicate mitotic cells with condensed chromosomes and no nuclear membrane. $(D)$ A mitotic index graph of IR and nocodazole-treated cells described in $B$ and $C$. Cells (250-300) were counted for each sample. GFP or Cre transfections are indicated by open or closed circles. $\mathrm{f} 5$ and $\mathrm{f} 6$ represent two independent $C H K 1^{\text {flox } /-}$ cell lines and $\mathrm{f} 7$ is a control CHK1 $1^{\text {flox/+ }}$ cell line. content as measured by FACS analysis (Fig. 4B). However, $40 \%-45 \%$ of Cre-transfected $\mathrm{CHK} 1^{\text {flox/- }}$ cells entered mitosis, in contrast to only $5 \%-8 \%$ of mitotic cells in GFP-transfected $\mathrm{CHK}^{\text {flox/- }}$ cells or Cre-transfected $\mathrm{CHK}^{+/+}$and $\mathrm{CHK}^{\text {flox/++}}$ control cells (Fig. 4C,D). Because $60 \%-70 \%$ of $C H K 1^{\text {flox/- }}$ cells are converted into $\mathrm{CHK}^{-1-}$ cells after PGK:Cre transfection, we estimate that at least $60 \%$ of $C H K 1^{-/-}$cells prematurely enter mitosis in spite of DNA damage. Thus, Chk 1 is a bona fide component of the mammalian $\mathrm{G}_{2} / \mathrm{M}$ DNA damage checkpoint. Furthermore, in response to DNA damage, the rapid kinetics and degree of inappropriate mitotic entry for $\mathrm{CHK}^{-/-}$cells suggest that Chk1 is required for the initiation of $\mathrm{G}_{2}$ arrest in response to DNA damage.

\section{CHK1 heterozygosity modestly enhances tumorigenesis of WNT-1 transgenic mice}

Examination of $\mathrm{CHK}^{+/-}$animals up to the age of 18 months failed to detect a predisposition to early tumori- genesis. To determine whether reduction of CHK1 dosage could enhance tumor formation in the context of other oncogenic stimuli, we crossed $\mathrm{CHK}^{+/-}$mice to WNT-1 transgenic mice, which contain a WNT-1 oncogene driven by a mammary gland-specific mouse mammary tumor virus promoter (Tsukamoto et al. 1988). The WNT-1 transgenic females develop early mammary gland hyperplasia and subsequent mammary adenocarcinomas at the ages of 3-12 months. Previous crosses of p53- and p21-deficient mice to WNT-1 transgenic mice have revealed synergistic enhancements of tumor incidence or tumor growth rates in the bitransgenic offspring (Donehower et al. 1995; Jones et al. 1999). After the

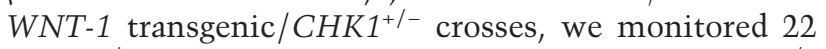
CHK1 ${ }^{+/-}$WNT-1 transgenic females and $22 \mathrm{CHK}^{+/+}$ WNT-1 transgenic females for tumors of the mammary gland. $\mathrm{CHK}^{+/-}$females showed an earlier onset of mammary tumors compared to the $C H K 1^{+/+}$females (Fig. 5). The average age of tumor formation in the $\mathrm{CHK} 1^{+/-}$ mice was 168 days versus 219 days for $\mathrm{CHK}^{+/+}$mice. 


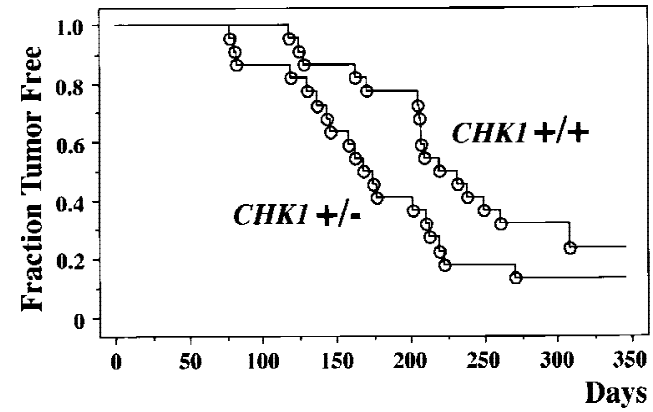

Figure 5. Kaplan-Meier plot of tumor incidence in $\mathrm{CHK1^{+/+ }}$ and $C H K 1^{+/-}$WNT-1 transgenic females. Twenty-two animals of each genotype were monitored for mammary tumor formation for $\sim 10$ months. Tumor-free survival is plotted against the animal age in days.

Statistical comparison of the tumor incidence curves by the log-rank test, the Breslow-Gehan-Wilcoxon test, and the Peto-Peto-Wilcoxon test gave $P$ values of 0.055 , 0.030 , and 0.030 , respectively. These test scores indicate that the differences in tumor incidence between the $\mathrm{CHK}^{+/+}$and $\mathrm{CHK}^{+/-}$mice are marginally significant at the 0.05 level.

Further comparison of the $\mathrm{CHK}^{+/+}$and $\mathrm{CHK}^{+/-}$ mammary adenocarcinomas revealed no obvious differences in gross pathology, histopathology, or growth rates. To assess whether the remaining wild-type CHK1 allele was lost in the $C H K 1^{+/-}$tumors, we analyzed genomic DNA isolated from $\mathrm{CHK}^{+/-}$tumors by Southern blot analysis. Of nine tumors examined, all nine retained an intact wild-type CHK1 allele (data not shown), suggesting that reduction of CHK1 dosage by $50 \%$ has a modest tumor-enhancing effect in the WNT-1 transgenic model. The retention of the wild-type CHK1 allele in the tumors is consistent with the finding that complete absence of Chk1 protein leads to cell lethality.

\section{In vivo phosphorylation of Chk1 on S345 by Atr} after DNA damage

In human cells, Chk1 is phosphorylated in response to DNA damage (Sanchez et al. 1997). Because SQ sites are known substrates of Atm and Atr (Banin et al. 1998; Canman et al. 1998), we raised rabbit polyclonal antibodies to peptides containing phosphorylated serine in the conserved SQ sites in human Chk1 protein. Only the anti-phospho-S345 (anti-p-S345) antibodies produced a signal specific for the phospho-antigen-peptide. Chk1 was immunoprecipitated with anti-Chk1 or anti-p-S345 antibodies from lysates prepared from $293 \mathrm{~T}$ cells that were either untreated or treated with hydroxyurea (HU), UV, or IR. Although the anti-Chk1 antibodies brought down equivalent amounts of Chk1 proteins from all cell lysates, the anti-p-S345 antibodies immunoprecipitated Chk1 proteins only from HU-, UV-, or IR-treated cells, but not from untreated cells (Fig. 6A). This experiment suggests that in human cells Chk1 is phosphorylated on S345 in response to DNA damage or replication blocks.
Because ATR and CHK1 disruptions both lead to periimplantation embryonic lethality in mice, we asked whether Atr regulates Chk1 in response to DNA damage. By transient transfection experiments, we showed that overexpression of wild-type Atr, but not the kinasedefective mutant Atr, increases the phosphorylation of co-transfected Chk1 on S345 in response to UV (Fig. 6B). Furthermore, overexpression of the kinase-defective mutant Atr in an inducible cell line (Cliby et al. 1998) inhibits the UV-induced S345 phosphorylation of endogenous Chk1 (Fig. 6C). These results suggest that Atr functions upstream of Chk1 in the mammalian DNA damage response pathway and is a major regulator of Chk1 phosphorylation after DNA damage.

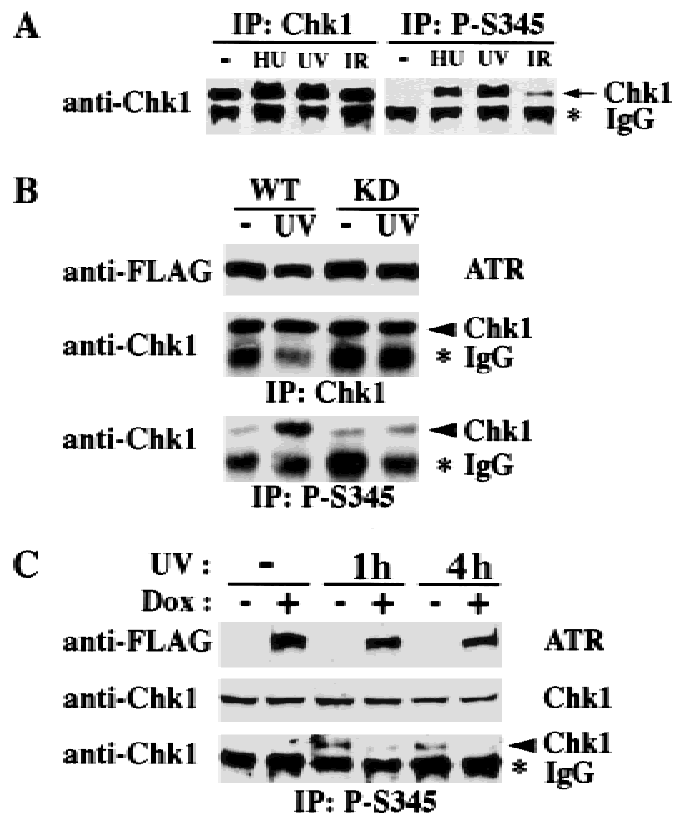

Figure 6. Chk1 is phosphorylated on S345 after DNA damage and this is regulated by Atr. (A) Phosphorylation of Chk1 on S345 after DNA damage. 293T cells were untreated or treated with IR (20 Gy and harvested after $1 \mathrm{hr}$ ), UV $\left(50 \mathrm{~J} / \mathrm{m}^{2}\right.$ and harvested after $2 \mathrm{hr}$ ) or $\mathrm{HU}$ ( $1 \mathrm{~mm}$ for $24 \mathrm{hr}$ ). Whole cell lysates were immunoprecipitated (IP) with rabbit anti-Chk1 or anti-p-S345 antibodies followed by immunoblotting with mouse anti-Chk1 antibodies. (B) Overexpression of wild-type (WT) but not kinasedeficient (KD) Atr enhances S345 phosphorylation of cotransfected Chk1. Thirty-six hours after cotransfection of $C M V: C h k 1$ and CMV:FLAG-Atr-WT or CMV-FLAG-Atr-KD, $293 \mathrm{~T}$ cells were untreated $(-)$ or treated with UV $\left(50 \mathrm{~J} / \mathrm{m}^{2}\right)$ and harvested after $1.5 \mathrm{hr}$. Whole cell lysates were immunoblotted with anti-FLAG antibodies to detect Atr expression, or assayed for S345 phosphorylation of Chk1 by IP-Western blot as described in $(A) .(C)$ Induction of kinase-deficient Atr inhibits S345 phosphorylation of endogenous Chk1. GM847/ATR-KD cells were cultured in the absence $(-)$ or presence $(+)$ of $1 \mu \mathrm{g} / \mathrm{ml}$ doxycycline (Dox) for $48 \mathrm{hr}$, untreated (-) or treated with UV (50 $\left.\mathrm{J} / \mathrm{m}^{2}\right)$ and harvested after $1(1 \mathrm{~h})$ or $4(4 \mathrm{~h}) \mathrm{hr}$. Whole cell lysates were immunoblotted with anti-FLAG or mouse anti-Chk1 antibodies to detect Atr-KD or endogenous Chk1 expression. And IP-Western was performed to detect S345 phosphorylation of Chk1 as described in $A$. 


\section{Discussion}

Chk1 is essential for embryonic development and ES cell survival

CHK1 deficiency leads to cell death in ES cells and periimplantation embryonic lethality in mice. Thus, the early lethality of $C H K 1$ null embryos can be explained by a cell autonomous failure of $\mathrm{CHK}^{-/-}$embryonic cells to survive. Given the essential role of Chk1 in each cell cycle, it is surprising that CHK1 null embryos can survive even to the blastocyst stage. A few embryonic divisions may be sustained in the CHK1 null embryos by maternal Chk1 protein stores. Alternatively, $\mathrm{CHK}^{-/-}$ embryonic cells may be capable of dividing a few times before apoptotic death. Regulated apoptosis occurs in wild-type murine blastocysts and is thought to eliminate redundant or damaged cells before implantation to ensure successful embryonic development (Parchment 1991). Thus, the massive apoptosis displayed by $C H K 1$ null blastocysts may indicate that $C H K 1^{-/-}$cells accumulate substantial genomic instability. The fact that apoptosis occurs independent of p53 in wild-type and CHK1 mutant blastocysts is consistent with the previous finding that ES cells undergo p53-independent apoptosis in response to DNA damage (Aladjem et al. 1998).

Although required for DNA damage checkpoints, CHK1 is not an essential gene in yeast $S$. cerevisiae or $S$. pombe. In contrast, Grapes/Chk1 is indispensable for early embryonic development in fruit flies and, as shown here, in mice. It remains unclear whether this embryonic lethality is due to the cell cycle checkpoint function of Chk1, or to some novel function acquired in evolution. It is known, however, that embryonic development is extremely sensitive to genomic instability. Consistently, disruption of many genes involved in double-stranded DNA break repair, including BRCA1, BRCA2, RAD50, RAD51, and MRE11, lead to early embryonic lethality in mice. Many of these genes have also been shown to be essential for ES cell viability and chromosomal stability (Hakem et al. 1996; Lim and Hasty 1996; Sharan et al. 1997; Luo et al. 1999; Yamaguchi-Iwai et al. 1999). Thus, if Chk1 mutant cells are checkpoint defective and cannot fully repair DNA damage during normal cell cycle, it might lead to the accumulation of genomic instability, cell death, and embryonic lethality.

\section{CHK1 and ATR may define a new class of tumor suppressors}

Given the degree of genomic instability seen in $A T R^{-/-}$ cells and possibly $C H K 1^{-/-}$cells, CHK1 and ATR are likely to be potent tumor suppressor genes. ATR heterozygotes have a small increase in tumor incidence (Brown and Baltimore 2000), whereas CHK1 heterozygosity modestly enhances the tumorgenicity of WNT-1 oncogenic mice. A limited analysis failed to detect any incidence of loss of heterozygosity $(\mathrm{LOH})$ in $A T R^{+/-}$or $\mathrm{CHK1}^{+/-}$tumors. This is consistent with the fact that complete absence of these proteins leads to cell lethality. Likewise, increase in spontaneous or carcinogen-induced tumor formation has been observed in p27 heterozygotes and some p53 heterozygotes without LOH (Fero et al. 1998; Venkatachalam et al. 1998). Because ATR and CHK1 are both essential genes that in the heterozygous state can modestly enhance tumorigenesis, they may represent a novel class of essential tumor suppressor genes that fail to display LOH in developing tumors. This also suggests that not all tumor suppressor genes can be detected by simply searching for mutations in the remaining allele of genes within a particular region of LOH. Thus, it might be prudent to give careful consideration to those genes believed to be essential for viability as important candidates for tumor suppressor genes.

\section{Chk1 is required for initiating $G_{2}$ arrest after $\gamma$-irradiation}

In response to IR, mouse ES cells arrest predominantly at $\mathrm{G}_{2}$ and Chk2 is required to maintain this arrest (Hirao et al. 2000). Similarily, p53, p21, and 14-3-3 sigma have been shown to help sustain the IR-induced $\mathrm{G}_{2}$ arrest in human fibroblast cells (Bunz et al. 1998; Chan et al. 1999|. Our analysis of the conditional CHK1-deficient ES cells indicates that Chk1 is primarily responsible for the initiation of $\mathrm{G}_{2}$ arrest in response to DNA damage. Chk1 and Chk2 have been shown to phosphorylate human Cdc25C on S216 in vitro (Furnari et al. 1997; Sanchez et al. 1997; Matsuoka et al. 1998; Blasina et al. 1999; Brown et al. 1999; Chaturvedi et al. 1999). S216 phosphorylation of Cdc25C is important for $\mathrm{G}_{2}$ arrest after DNA damage (Peng et al. 1997) because it causes inhibition and cytoplasmic sequestration of Cdc25C, thereby preventing the activation of Cdc2 kinase (Kumagai and Dunphy 1999; Lopez-Girona et al. 1999; Yang et al. 1999). Because the S216 site is not conserved in mouse Cdc25C, other similarly acting phosphorylation sites may exist as targets of these checkpoint kinases. Furthermore, it is likely that additional targets for Chk 1 and Chk2 also contribute to cell cycle arrest ( $\mathrm{O}^{\prime}$ Connell et al. 1997). Our results are consistent with the model in which Chk1 primarily functions to initiate the $\mathrm{G}_{2}$ arrest in response to DNA damage and Chk2 plays a supporting role in maintaining this arrest both by preventing the activation of Cdc2 kinase through Cdc25C. Because mouse ES cells have an unusual cell cycle, it will be important to study Chk1 and Chk2 function in DNA damage checkpoints in other cell types.

\section{Chk1 is modified in response to DNA damage}

In yeast and humans, Chk1 is phosphorylated in response to DNA damage (Walworth et al. 1993; Sanchez et al. 1997, 1999). The phosphorylation of human Chk1 can only be reliably detected by two-dimensional gel analysis. To establish a simpler assay for Chk1 activation, we made phospho-specific antibodies and found that anti-p-S345 antibodies were able to immunoprecipitate Chk1 efficiently only when cells were treated with DNA-damaging or replication-interfering agents such as $\mathrm{UV}$ and HU, and to a lesser extent with IR. Analysis of 
Chk1 phosphorylation was complicated by the fact that it runs on a gel at a position obscured by the heavy chain of IgG. The assay we used could not distinguish regulated phosphorylation of Chk1 on S345 versus constitutive phosphorylation with regulated accessibility by antibodies. However, given the knowledge of Chk1 phosphorylation in other systems, we favor the idea that human Chk1 is phosphorylated on S345 in response to DNA damage or replication blocks. The S345 site ISF(pS)QP is very similar to the consensus 14-3-3 binding sequence $\mathrm{RSx}(\mathrm{pS}) \mathrm{xP}$, suggesting that phosphorylated human Chk1 protein may interact with 14-3-3 proteins. Phosphorylation of this conserved site in $S$. pombe Chk1 could potentially explain the increase in 14-3-3 binding to Chk1 after DNA damage (Chen et al. 1999).

\section{Atr regulates Chk1}

Both Atr/Mei-41 and Chk1/Grapes are required for early embryogenesis in mice and fruit flies, suggesting Atr and Chk1 function in the same pathway. We propose that Atr is a major regulator of Chk1 in response to DNA damage based on the following observations: (1) Chk1 phosphorylation on S345 is increased in response to UV and HU treatment, to which cells expressing kinase-defective mutant Atr show enhanced sensitivity (Cliby et al. 1998); (2) overexpression of Atr enhances Chk1 S345 phosphorylation in response to UV; (3) Atr can phosphorylate the S345 site in vitro when presented as a GST fusion peptide (Kim et al. 1999); (4) overexpression of the kinase-defective mutant Atr reduces S345 phosphorylation of endogenous Chk1 in response to UV; and (5) like $\mathrm{CHK}^{-/-}$cells, cells expressing the kinase-defective mutant Atr are compromised for the IR-induced $\mathrm{G}_{2}$ arrest (Cliby et al. 1998). Taken together, these results suggest that Atr functions upstream of Chk1 and regulate its phosphorylation on S345 in response to DNA damage.

Our results are consistent with a model shown in Figure 7, in which Atm-Chk2 and Atr-Chk1 represent two parallel branches in the mammalian DNA damage response pathway that respond primarily toward different types of DNA damage. Atm responds primarily to DNAdamaging agents that cause double-stranded breaks, such

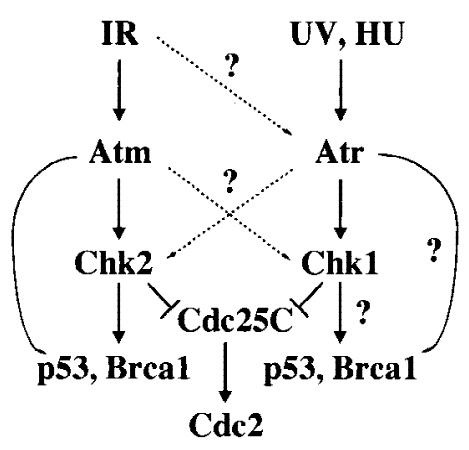

Figure 7. A model for the mammalian DNA damage response pathway (See text for details). The question marks indicate hypothetical regulatory interactions. as IR, and phosphorylates Chk2. Atm and Chk2 together phosphorylate Brca1 and p53 (Banin et al. 1998; Canman et al. 1998; Cortez et al. 1999; Chehab et al. 2000; Hirao et al. 2000; Shieh et al. 2000), and activate cellular responses including $G_{1}$ arrest. On the other hand, Atr responds primarily to agents like UV and HU that can potentially interfere with DNA replication, and phosphorylates Chk1. It is possible that Atr and Chk1 phosphorylate Brca1, p53 in addition to Cdc25C (Tibbetts et al. 1999; Shieh et al. 2000; R.S. Tibbetts et al., in prep.), and activate cellular responses including $G_{2}$ arrest. Furthermore, the two pathways have significant overlap and often cooperate with each other to ensure prompt and efficient repair of DNA damage and to maintain genomic integrity. When one pathway is genetically compromised, they can also function redundantly, although probably to a lesser extent and with different kinetics. For example, the rapid p53 stabilization in response to IR is greatly reduced in ATM mutant cells (Kastan et al. 1992), but it does occur much later, which is probably due to Atr (Lu and Lane 1993; Tibbetts et al. 1999). Similar observations have been made for Chk2 phosphorylation in response to IR (S. Matsuoka and S.J. Elledge, unpubl.). This may reflect the fact that in addition to tailoring the cellular response to different types of DNA damage, cells have many responses that are commonly required toward different types of genotoxic stress.

\section{Materials and methods}

\section{Construction of targeting vectors}

All targeting vectors were constructed for positive-negative selection and thus contain a neo or hprt marker and a TK marker. For simplification, we describe the composition of each vector rather than details of construction. Neo-targeting vector (pQL258): The neo marker was flanked by $1.9 \mathrm{~kb}$ of the $5^{\prime}$ untranslated region and $4.5 \mathrm{~kb}$ of genomic sequence containing exons 6-7. Hprt-targeting vector (pQL289): The hprt marker was flanked by $3 \mathrm{~kb}$ of $5^{\prime}$ genomic sequence with exon 2 and $4.2 \mathrm{~kb}$ of $3^{\prime}$ genomic sequence with exons 6-7. Flox targeting vector (pQL456): The loxP-neo-loxP cassette was ligated to a 2.2-kb exon 2-containing genomic sequence, of which the last $59 \mathrm{bp}$ was replaced by an EcoRV and a loxP site. The loxP-neo-loxPE2-RV-loxP centerpiece was flanked by $1.9 \mathrm{~kb}$ of $5^{\prime}$ untranslated region and $4.3 \mathrm{~kb}$ of $3^{\prime}$ genomic sequence carrying exons 3-5.

\section{Southern blot and PCR}

Genomic DNA was isolated from ES cells or mouse tissues using standard protocols and Southern blot analysis were performed with QuikHyb solution (Stratagene). The 3' external probe was a 420-bp HindIII-NheI fragment from pQL253, whereas the 5' internal probe was a 1.4-kb EcoRI-XhoI fragment from pQL286. WNT-1 and p53 genotyping was performed as described (Tsukamoto et al. 1988; Donehower et al. 1992). Preimplantation embryos were digested at $55^{\circ} \mathrm{C}$ overnight in lysis buffer [10 mм Tris (pH 7.5), 10 mм EDTA (pH 8), 10 mм NaCl, $0.5 \%$ Sarcosyl, $0.5 \mathrm{mg} / \mathrm{ml}$ protease $\mathrm{K}]$ and $1-5 \mu l$ lysate was used for PCR. CHK1 PCR was conducted in $25 \mu \mathrm{l}$ reaction using Expand DNA polymerase (Boehringer Mannheim) and three primers: 247, 5'-ACCGCTTCCTCGTGCTTTAC-3'; 248, 5'ATAGGCACCTTCTCCCAAAG-3'; and 252, 5'-GGAGGA- 
CAAACGTGGAAACAGG-3'. PCR cycles: $94^{\circ} \mathrm{C}, 3 \mathrm{~min}, 33$ cycles of $\left(94^{\circ} \mathrm{C}, 20 \mathrm{sec} ; 63^{\circ} \mathrm{C}, 60 \mathrm{sec}\right), 68^{\circ} \mathrm{C}, 4 \mathrm{~min}$. A 282 -bp and a 572-bp fragment were amplified from the wild type (by 248 and 252) and mutant alleles (by 247 and 252), respectively.

\section{Manipulations of pre-implantation embryos}

All embryos were generated by natural matings. Eight-cell morula were cultured in KSOM media (Cell and Molecular Technologies) and blastocysts in M15 media. All images of in vitro cultured embryos were taken on an inverted microscope using the National Institutes of Health (NIH) imaging software.

\section{TUNEL analysis of blastocysts}

Eight-cell morula were isolated, cultured for $45 \mathrm{hr}$ and harvested for TUNEL analysis according to manufacture's protocol (Boehringer Mannheim). In brief, embryos were fixed in $10 \%$ formalin for $20 \mathrm{~min}$, permeablized in $0.2 \%$ Triton X-100 for $5 \mathrm{~min}$, followed by TUNEL labeling at $37^{\circ} \mathrm{C}$ for $1 \mathrm{hr}$ and DAPI staining. Stained embryos were individually suspended in PBS solution for imaging on a Zeiss fluorescence microscope. Mutant and normal-looking embryos were divided into two groups: half for genotyping and half mounted for confocal imaging. Normal $\left(\mathrm{CHK}^{+/+}\right.$and $\left.\mathrm{CHK1}^{+/-}\right)$versus mutant $\left(\mathrm{CHK}^{-/-}\right)$embryos were identified with $\sim 95 \%$ confidence.

\section{FACS and mitotic index}

FACS analysis was performed with standard protocols. Feeder cells were excluded based on their giant size and greater than $4 \mathrm{~N}$ DNA content. The percentage of $\mathrm{G}_{1}-\mathrm{S}$ and $\mathrm{G}_{2}$ population was measured by the Coulter (II) software (Beckman). For mitotic index measurement, cells were cytospinned onto slides, fixed in 3\% paraformaldehyde for $15 \mathrm{~min}$, permeablized in $0.5 \%$ NP40 for 5 min, and mounted in Vectashield containing DAPI (Vector Lab). Feeder cells were excluded based on their giant size and multinuclei.

\section{Antibodies}

Mouse anti-FLAG (M5) (Sigma) and anti-Chk1 (Santa Cruz) antibodies were purchased and rabbit anti-(human) Chk1 antibodies were described in Sanchez et al. (1997). The anti-p-S345 antibodies were raised against a human Chk1 phospho-S345 peptide, QGISF $(\mathrm{pS}) \mathrm{QPTC}$, and were affinity-purified by the phospho-antigen-peptide column followed by passing through a QGISFSQPTC peptide column to eliminate nonspecific antibodies reacting with the unphosphorylated antigen peptide. Cell lysates were prepared and immunoprecipitation (IP) were performed as described (Matsuoka et al. 1998). IP with anti-pS345 antibodies was conducted in the presence of $100 \mu \mathrm{g} / \mathrm{ml}$ of the QGISFSQPTC peptide. Immunoblots were visualized by ECL (Amersham).

\section{Acknowledgments}

We thank Drs. Yolonda Sanchez, Stephen H. Friend, Karlene A. Cimprich, Philippe Soriano, and Richard Behringer for useful plasmids and reagents, Janet C. Thompson, Louise A. Stanley, and Jessica Wang for technical assistance. We also thank Dr. Michael A. Mancini for generous help on confocal imaging, Drs. Pauline Ward and Zhengzheng Shi for technical advice on manipulation of preimplantation embryos, and Hua Chang, Drs. Tony Carr, Nancy Walworth, Eric Brown, William Sullivan, An- thony Lau, and Pumin Zhang for helpful discussions. X.C. is supported by Karolinska Institute (Sweden)/BCM exchange program and the U.S. Army Breast Cancer Research program. L.A.D. is the recipient of a U.S. Army Breast Cancer Research Program academic award. This work was also supported by NIH grants awarded to S.J.E. and A.B. Both are investigators with the Howard Hughes Medical Institute.

The publication costs of this article were defrayed in part by payment of page charges. This article must therefore be hereby marked "advertisement" in accordance with 18 USC section 1734 solely to indicate this fact.

\section{References}

Aladjem, M.I., B.T. Spike, L.W. Rodewald, T.J. Hope, M. Klemm, R. Jaenisch, and G.M. Wahl. 1998. ES cells do not activate p53-dependent stress responses and undergo p53independent apoptosis in response to DNA damage. Curr. Biol. 8: 145-155.

Al-Khodairy, F., E. Fotou, K.S. Sheldrick, D.J. Griffiths, A.R. Lehmann, and A.M. Carr. 1994. Identification and characterization of new elements involved in checkpoint and feedback controls in fission yeast. Mol. Biol. Cell. 5: 147-160.

Banin, S., L. Moyal, S. Shieh, Y. Taya, C.W. Anderson, L. Chessa, N.I. Smorodinsky, C. Prives, Y. Reiss, Y. Shiloh et al. 1998. Enhanced phosphorylation of p53 by ATM in response to DNA damage. Science 281: 1674-1677.

Barlow, C., S. Hirotsune, R. Paylor, M. Liyanage, M. Eckhaus, F. Collins, Y. Shiloh, J.N. Crawley, T. Ried, D. Tagle et al. 1996. Atm-deficient mice: A paradigm of ataxia telangiectasia. Cell 86: 159-171.

Blasina, A., D. Weyer IV, M.C. Laus, W.H. Luyten, A.E. Parker, and C.H. McGowan. 1999. A human homologue of the checkpoint kinase Cds1 directly inhibits Cdc25 phosphatase. Curr. Biol. 9: 1-10.

Boddy, M.N., B. Furnari, O. Mondesert, and P. Russell. 1998. Replication checkpoint enforced by kinases Cds1 and Chk1. Science 280: 909-912.

Brown, A.L., C.H. Lee, J.K. Schwarz, N. Mitiku, H. PiwnicaWorms, and J.H. Chung. 1999. A human Cds1-related kinase that functions downstream of ATM protein in the cellular response to DNA damage. Proc. Natl. Acad. Sci. 96: 37453750.

Brown, E.J. and D. Baltimore. 2000. ATR disruption leads to chromosomal fragmentation and early embryonic lethality. Genes \& Dev. 14: 397-402.

Bunz, F., A. Dutriaux, C. Lengauer, T. Waldman, S. Zhou, J.P. Brown, J.M. Sedivy, K.W. Kinzler, and B. Vogelstein. 1998. Requirement for p53 and p21 to sustain G2 arrest after DNA damage. Science 282: 1497-1501.

Canman, C.E., D.S. Lim, K.A. Cimprich, Y. Taya, K. Tamai, K. Sakaguchi, E. Appella, M. B. Kastan, and J.D. Siliciano. 1998. Activation of the ATM kinase by ionizing radiation and phosphorylation of p53. Science 281: 1677-1679.

Chan, T.A., H. Hermeking, C. Lengauer, K.W. Kinzler, and B. Vogelstein. 1999. 14-3-3Sigma is required to prevent mitotic catastrophe after DNA damage. Nature 401: 616-620.

Chaturvedi, P., W.K. Eng, Y. Zhu, M.R. Mattern, R. Mishra, M.R. Hurle, X. Zhang, R.S. Annan, Q. Lu, L.F. Faucette et al. 1999. Mammalian Chk2 is a downstream effector of the ATM-dependent DNA damage checkpoint pathway. Oncogene 18: 4047-4054.

Chehab, N.H., A. Malikzay, M. Appel, and T.D. Halazonetis. 2000. Chk2/hCds1 functions as a DNA damage checkpoint in $\mathrm{G}(1)$ by stabilizing p53. Genes \& Dev. 14: 278-288. 
Chen, L., T.H. Liu, and N.C. Walworth. 1999. Association of Chk1 with 14-3-3 proteins is stimulated by DNA damage. Genes \& Dev. 13: 675-685.

Cimprich, K.A., T.B. Shin, C.T. Keith, and S.L. Schreiber. 1996. cDNA cloning and gene mapping of a candidate human cell cycle checkpoint protein. Proc. Natl. Acad. Sci. 93: 2850-2855.

Cliby, W.A., C.J. Roberts, K.A. Cimprich, C.M. Stringer, J.R. Lamb, S.L. Schreiber, and S.H. Friend. 1998. Overexpression of a kinase-inactive ATR protein causes sensitivity to DNAdamaging agents and defects in cell cycle checkpoints. ЕМВО J. 17: 159-169.

Cortez, D., Y. Wang, J. Qin, and S.J. Elledge. 1999. Requirement of ATM-dependent phosphorylation of Brcal in the DNA damage response to double-strand breaks. Science 286: 11621166.

Donehower, L.A., M. Harvey, B.L. Slagle, M.J. McArthur, C.A. Montgonery Jr., J.S. Butel, and A. Bradley. 1992. Mice deficient for p53 are developmentally normal but susceptible to spontaneous tumors. Nature 356: 215-221.

Donehower, L.A., L.A. Godley, C.M. Aldaz, R. Pyle, Y.P. Shi, D. Pinkel, J. Gray, A. Bradley, D. Medina, and H.E. Varmus. 1995. Deficiency of p53 accelerates mammary tumorigenesis in Wnt-1 transgenic mice and promotes chromosomal instability. Genes \& Dev. 9: 882-895.

Elledge, S.J. 1996. Cell cycle checkpoints: Preventing an identity crisis. Science 274: 1664-1672.

Fero, M.L., E. Randel, K.E. Gurley, J.M. Roberts, and C.J. Kemp. 1998. The murine gene $\mathrm{p} 27 \mathrm{Kip} 1$ is haplo-insufficient for tumour suppression. Nature 396: 177-180.

Fogarty, P., S.D. Campbell, R. Abu-Shumays, B.S. Phalle, K.R. Yu, G.L. Uy, M.L. Goldberg, and W. Sullivan. 1997. The Drosophila grapes gene is related to checkpoint gene chk1/ $\operatorname{rad} 27$ and is required for late syncytial division fidelity. Curr. Biol. 7: 418-426.

Furnari, B., N. Rhind, and P. Russell. 1997. Cde25 mitotic inducer targeted by chk1 DNA damage checkpoint kinase. Science 277: 1495-1497.

Hakem, R., J.L. de la Pompa, C. Sirard, R. Mo, M. Woo, A. Hakem, A. Wakeham, J. Potter, A. Reitmair, F. Billia et al. 1996. The tumor suppressor gene Brcal is required for embryonic cellular proliferation in the mouse. Cell 85: 10091023.

Hirao A., Y. Kong, S. Matsuoka, A. Wakeham, J. Ruland, H. Yoshida, D. Liu, S.J. Elledge, and T.W. Mak. 2000. DNA damage-induced activation of p53 by the checkpoint kinase Chk2. Science 287: 1824-1827.

Jones, J.M., X.-S. Cui, D. Medina, and L.A. Donehower. 1999. Heterozygosity of $\mathrm{p} 21$ WAF1/CIP1 enhances tumor cell proliferation and cyclin D1-associated kinase activity in a murine mammary cancer model. Cell Growth Differ. 10: 213222.

Kastan, M.B., Q. Zhan, W.S. el-Deiry, F. Carrier, T. Jacks, W.V. Walsh, B.S. Plunkett, B. Vogelstein, and A.J. Fornace. 1992. A mammalian cell cycle checkpoint pathway utilizing p53 and GADD45 is defective in ataxia-telangiectasia. Cell 71: 587597.

Keegan, K.S., D.A. Holtzman, A.W. Plug, E.R. Christenson, E.E. Brainerd, G. Flaggs, N.J. Bentley, E.M. Taylor, M.S. Meyn, S.B. Moss et al. 1996. The Atr and Atm protein kinases associate with different sites along meiotically pairing chromosomes. Genes \& Dev. 10: 2423-2437.

Kim, S.T., D.S. Lim, C.E. Canman, and M.B. Kastan. 1999. Substrate specificities and identification of putative substrates of ATM kinase family members. J. Biol. Chem. 274: 3753837543.

Kumagai, A. and W.G. Dunphy. 1999. Binding of 14-3-3 proteins and nuclear export control the intracellular localization of the mitotic inducer Cdc25. Genes \& Dev. 13: 1067-1072.

Kumagai A., Z. Guo, K.H. Emami, S.X. Wang, and W.G. Dunphy. 1998. The Xenopus Chk1 protein kinase mediates a caffeine-sensitive pathway of checkpoint control in cell-free extracts. J. Cell. Biol. 142: 1559-1569.

Lim, D.S. and P. Hasty. 1996. A mutation in mouse rad51 results in an early embryonic lethal that is suppressed by a mutation in p53. Mol. Cell. Biol. 16: 7133-7143.

Lindsay, H.D., D.J. Griffiths, R.J. Edwards, P.U. Christensen, J.M. Murray, F. Osman, N. Walworth, and A.M. Carr. 1998. S-phase-specific activation of Cds1 kinase defines a subpathway of the checkpoint response in Schizosaccharomyces pombe. Genes \& Dev. 12: 382-395.

Lopez-Girona, A., B. Furnari, O. Mondesert, and P. Russell. 1999. Nuclear localization of Cdc25 is regulated by DNA damage and a 14-3-3 protein. Nature 397: 172-175.

$\mathrm{Lu}, \mathrm{X}$. and D.P. Lane. 1993. Differential induction of transcriptionally active p53 following UV or ionizing radiation: Defects in chromosome instability syndromes? Cell 75: 765778.

Luo, G., M.S. Yao, C.F. Bender, M. Mills, A.R. Bladl, A. Bradley, and J.H. Petrini. 1999. Disruption of mRad50 causes embryonic stem cell lethality, abnormal embryonic development, and sensitivity to ionizing radiation. Proc. Natl. Acad. Sci. 96: 7376-7381.

Matsuoka, S., M. Huang, and S.J. Elledge. 1998. Linkage of ATM to cell cycle regulation by the Chk 2 protein kinase. Science 282: $1893-1897$.

Nakajo, N., T. Oe, K. Uto, and N. Sagata. 1999. Involvement of Chk1 kinase in prophase I arrest of Xenopus oocytes. Dev. Biol. 207: 432-444.

O'Connell, M.J., J.M. Raleigh, H.M. Verkade, and P. Nurse. 1997. Chk1 is a wee1 kinase in the G2 DNA damage checkpoint inhibiting edc2 by Y15 phosphorylation. EMBO $\mathrm{T}$. 16: $545-554$.

Parchment, R.E. 1991. Programmed cell death (apoptosis) in murine blastocysts: Extracellular free-radicals, polyamines, and other cytotoxic agents. In Vivo 5: 493-500.

Peng, C-Y., P.R. Graves, R.S. Thoma, Z. Wu, A.S. Shaw, and H. Piwnica-Worms. 1997. Mitotic and G2 checkpoint control: Regulation of 14-3-3 protein binding by phosphorylation of Cdc25C on serine-216. Science 277: 1501-1505.

Sanchez, Y., B.A. Desany, W.J. Jones, Q, Liu, B. Wang, and S.J. Elledge. 1996. Regulation of RAD53 by the ATM-like kinases MECl and TEL1 in yeast Cell Cycle Checkpoint Pathways. Science 271: 357-360.

Sanchez, Y., C. Wong, R.S. Thoma, R. Richman, Z. Wu, H. Piwnica-Worms, and S.J. Elledge. 1997. Conservation of the Chk1 checkpoint pathway in mammals: Linkage DNA damage to Cdk regulation through Cdc25. Science 277: 14971501.

Sanchez, Y., J. Bachant, H. Wang, F. Hu, D. Liu, M. Tetzlaff, and S.J. Elledge. 1999. Control of the DNA damage checkpoint by chk1 and rad53 protein kinases through distinct mechanisms. Science 286: 1166-1171.

Savitsky, K., A. Bar-Shira, S. Gilad, G. Rotman, Y. Ziv, L. Vanagaite, D.A. Tagle, S. Smith, T. Uziel, S. Sfez et al. 1995. A single ataxia telangiectasia gene with a product similar to PI-3 kinase. Science 268: 1749-1753.

Sharan, S.K., M. Morimatsu, U. Albrecht, D.S. Lim, E. Regel, C. Dinh, A. Sands, G. Eichele, P. Hasty, and A. Bradley. 1997. Embryonic lethality and radiation hypersensitivity mediated by Rad51 in mice lacking Brca2. Nature 386: 804-810.

Shieh, S.Y., J. Ahn, K. Tamai, Y. Taya, and C. Prives. 2000. The human homologs of checkpoint kinases chk1 and cds1 
(Chk2) phosphorylate p53 at multiple DNA damage-inducible sites. Genes \& Dev. 14: 289-300.

Sibon, O.C., V.A. Stevenson, and W.E. Theurkauf. 1997. DNAreplication checkpoint control at the Drosophila midblastula transition. Nature 388: 93-97.

Sibon, O.C., A. Laurencon, R. Hawley, and W.E. Theurkauf. 1999. The Drosophila ATM homologue Mei-41 has an essential checkpoint function at the midblastula transition. Curr. Biol. 9: 302-312.

Su, T.T., S.D. Campbell, and P.H. O'Farrell. 1999. Drosophila grapes/CHK1 mutants are defective in cyclin proteolysis and coordination of mitotic events. Curr. Biol. 9: 919-922.

Sun, Z., D.S. Fay, F. Marini, M. Foiani, and D.F. Stern. 1996. Spk1/Rad53 is regulated by Mec1-dependent protein phosphorylation in DNA replication and damage checkpoint pathways. Genes \& Dev. 10: 395-406.

Tibbetts, R.S., K.M. Brumbaugh, J.M. Williams, J.N. Sarkaria, W.A. Cliby, S.Y. Shieh, Y. Taya, C. Prives, and R.T. Abraham. 1999. A role for ATR in the DNA damage-induced phosphorylation of p53. Genes \& Dev. 13: 152-157.

Tsukamoto, A.S., R. Grosschedl, R.C. Guman, T. Parslow, and H.E. Varmus. 1988. Expression of the int-1 gene in transgenic mice is associated with mammary gland hyperplasia and adenocarcinomas in male and female mice. Cell 55: 619625.

Venkatachalam, S., Y.P. Shi, S.N. Jones, H. Vogel, A. Bradley, D. Pinkel, and L.A. Donehower. 1998. Retention of wild-type p53 in tumors from p53 heterozygous mice: Reduction of p53 dosage can promote cancer formation. EMBO J. 17: 46574667.

Walworth, N.C. and R. Bernards. 1996. Rad-dependent response of the chk1-encoded protein kinase at the DNA damage checkpoint. Science 271: 353-356.

Walworth, N., S. Davey, and D. Beach. 1993. Fission yeast chk1 protein kinase links the rad checkpoint pathway to cdc2. Nature 363: 368-371.

Wright, J.A., K.S. Keegan, D.R. Herendeen, N.J. Bentley, A.M. Carr, M.F. Hoekstra, and P. Concannon. 1998. Protein kinase mutants of human ATR increase sensitivity to UV and ionizing radiation and abrogate cell cycle checkpoint control. Proc. Natl. Acad. Sci. 95: 7445-7450.

Xu, Y., T. Ashley, E.E. Brainerd, R.T. Bronson, M.S. Meyn, and D. Baltimore. 1996. Targeted disruption of ATM leads to growth retardation, chromosomal fragmentation during meiosis, immune defects, and thymic lymphoma. Genes \& Dev. 10: 2411-2422.

Yamaguchi-Iwai, Y., E. Sonoda, M.S. Sasaki, C. Morrison, T. Haraguchi, Y. Hiraoka, Y.M. Yamashita, T. Yagi, M. Takata, C. Price et al. 1999. Mre11 is essential for the maintenance of chromosomal DNA in vertebrate cells. EMBO J. 18: 66196629.

Yang, J., K. Winkler, M. Yoshida, and S. Kornbluth. 1999. Maintenance of G2 arrest in the Xenopus oocyte: A role for 14-33-mediated inhibition of Cdc25 nuclear import. EMBO J. 18: $2174-2183$. 


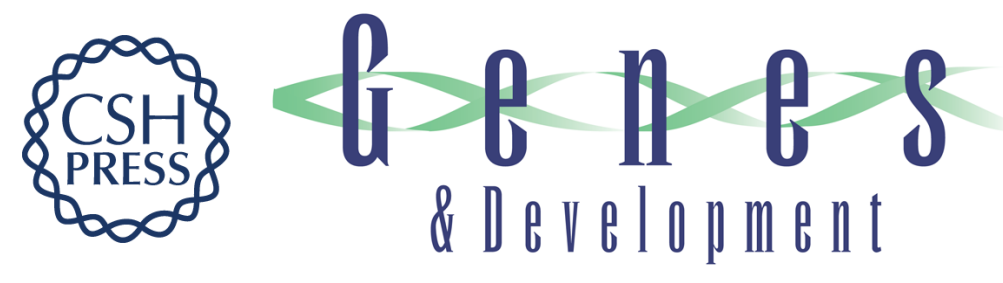

\section{Chk1 is an essential kinase that is regulated by Atr and required for the $\mathrm{G}_{2}$ /M DNA damage checkpoint}

Qinghua Liu, Saritha Guntuku, Xian-Shu Cui, et al.

Genes Dev. 2000, 14:

Access the most recent version at doi:10.1101/gad.14.12.1448

References

This article cites 60 articles, 40 of which can be accessed free at: http://genesdev.cshlp.org/content/14/12/1448.full.html\#ref-list-1

License

Email Alerting

Receive free email alerts when new articles cite this article - sign up in the box at the top Service right corner of the article or click here.

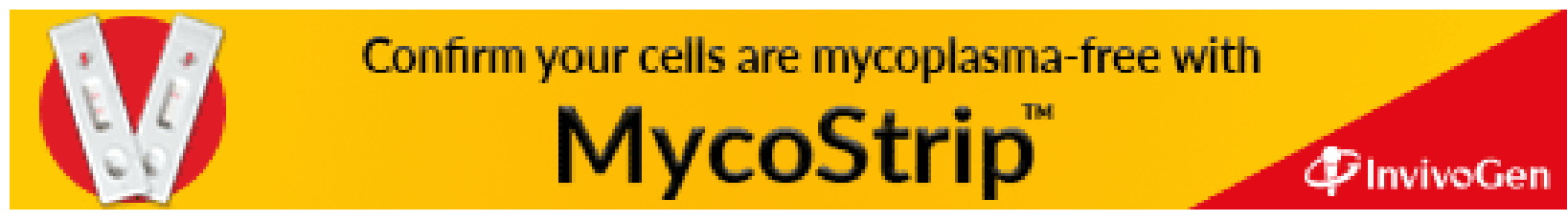

